\title{
Strategi Jitu Menggalang Angka Kecukupan Mahasiswa Baru Di Tengah Persaingan Sengit Antar Perguruan Tinggi
}

\author{
Panji Sekar Pambudi \\ Universitas PGRI Banyuwangi \\ panji4you@gmail.com \\ Moh. Sabiq Irwan Hariandi \\ Universitas PGRI Banyuwangi \\ irwan.hariandi@gmail.com
}

\begin{abstract}
The intense competition between public and private universities in Banyuwangi district in finding a sufficient number of new students is an interesting phenomenon. The purpose of this research is to find out an appropriate strategy to fulfill the adequacy rate of new student candidates at University of PGRI Banyuwangi (UNIBA). This research was conducted in Banyuwangi district with 200 samples of public and private high school / vocational students, 20 Counseling Guidance teachers, 200 student's parents and 50 new students who are studying in the first semester. The research instruments used in this study are questionnaires and interviews. This study used a qualitative approach, then data were analyzed using SWOT. The result of this studyis a form of implementing an aggressive SWOT strategy as follows: 1) Strengths-Opportunities (S-O) Strategy, 2) Strenghts-Threats (S-T) Strategy, 3) WeaknessesOpportunities (W-O) Strategy. 4) Weaknesses-Threats (W-T) Strategy
\end{abstract}

Keywords: Accurate Strategy, Student Adequacy Rate

\section{Article Info}

\section{PENDAHULUAN}

Sejak berkembangnya Kab.
Banyuwangi sebagai destinasi wisata
Internasional, investasi di daerah dengan
julukan 'Sunrise Of Java' ini didapati cukup
tinggi, tak terkecuali dalam bidang investasi
pendidikan tinggi. Empat tahun belakangan
telah berdiri beberapa kampus swasta baru yang
menawarkan jurusan-jurusan dan program studi
yang menarik bagi calon mahasiswa. Sebagai
suatu daerah yang berkembang, berdiriya
sebuah kampus merupakan salah satu indikator
peningkatan kualitas sumber daya manusia.

Menjelang berakhirnya tahun pelajaran semester genap bagi siswa SMA Kelas XII, merupakan saat yang paling tepat bagi perguruan tinggi untuk mempromosikan diri. Berbagai macam pilhan jalur masuk calon mahasiswa baru ditawarkan oleh tiap perguruan tinggi, mulai dari Sistem Seleksi Masuk Perguruan Tinggi (SMPT) resmi pemerintah sampai dengan jalur undangan (reguler dan non reguler). Hal tersebut tergolong lazim, dikarenakan setiap perguruan tinggi memang mempunyai otonomi untuk berkembang dan mengatur rumah tangganya sendiri (PP No. 61 
tahun 1999 tentang Otonomi Perguruan Tinggi). Dengan demikian, penggalangan calon mahasiswa baru merupakan tantangan bagi semua perguruan tinggi agar dapat terus hidup dan berkembang dengan tanpa mengabaikan kualitas dan kuantitas jumlah mahasiswa, termasuk di dalamnya juga perguruan tinggi swasta dalam memproporsionalkan rasio jumlah dosen dan mahasiswa sesuai amanat (Permenristekdikti, 2016).

Investasi di dunia pendidikan diyakini sebagai bentuk upaya yang tepat sebagai wujud perbaikan kualitas diri dalam rangka menyambut perubahan dan tantangan zaman kedepan. Oleh karena itu perguruan tinggi sebagai media perubahan, hendaknya mampu memberikan pelayanan terbaik bagi mahasiswa dalam pencapaian karir, yang diwujudkan dengan cara memberikan pendidikan yang berkualitas dan berdaya saing tinggi dalam kancah nasional maupun internasional (Garaika \& Feriyan, 2018).

Program Studi Penjaskes \& Rek. Universitas PGRI Banyuwangi berdiri pada tanggal 11 Juli 2007. Pada tahun 2009-2014, Prodi. Penjaskesrek pernah mengalami jumlah puncak mahasiswa sekitar 4000-an mahasiswa pada semua angkatan. Namun demikian, pada tahun 2019-2020 calon mahasiswa baru menurun drastis pada angka puluhan saja. Hal ini merupakan masalah serius dan urgent, dikarenakan penurunan angka mahasiswa baru berdampak serius serta bekonsekwensi negatif bagi kondisi finansial lembaga secara umum.

Upaya mengatasi masalah berkurangnya calon mahasiswa baru dengan promosi sudah dilakukan secara optimal, namun demikian hasilnya masih belum seperti yang diharapkan. Biasanya masalah yang sering terjadi dalam ajang promosi lembaga untuk mahasiswa baru adalah strategi tujuan yang kurang realistis, strategi yang keliru, strategi yang tidak perlu dan strategi yang nampak benar namun tidak berhasil (Sopandi, 2011), (Maxsi, 2015).

Promosi kampus untuk mahasiswa baru, memang hal yang menarik karena mampu menumbuhkan inovasi dan kreatifitas dalam hal penyampaian informasi yang berupa promosi keunggulan dan potensi tiap perguruang tinggi, meski demikian juga penting mengetahui minat, motivasi serta pangsa pasar 'calon mahasiswa' untuk melanjutkan pendidikannya kelak setelah lulus SMA. Dengan demikian penetapan strategi 'jitu' sebagai bentuk upaya untuk menumbuhkan daya tarik dalam hal pemenuhan angka kecukupan mahasiswa baru, menjadi hal mendasar untuk dikaji dalam upaya mempertahankan eksistensi sebuah lembaga pendidikan tinggi di tengah-tengah persaingan ketat antar perguruan tinggi di Banyuwangi, tanpa harus selalu menonjolkan kuantitas dan mengkesampingkan kualitas dan mutu pendidikan. Umumya setelah produk tersedia maka, hal berikutnya yang perlu dilakukan adalah memasarkan produk. Produk dapat berupa barang, jasa, tempat, organisasi maupun gagasan yang ditawarkan pada pasar dalam rangka mencapai kepuasaan pelanggan Kotler dalam (Zaman, 2017). Pemasaran merupakan upaya menyampaikan rangkaian informasi kepada masyarakat atau pengguna produk. Sasaran atau segmentasi pasar sudah semestinya menjadi dasar perencanaan yang jelas dan logis sebagai target/bidikan, karena berhubungan erat dengan pencapaian yang ingin diraih. Komunikasi yang efektif merupakan bentuk strategi pemasaran atas relevansinya pada tujuan atau muara yang hendak dicapai.

Dalam bidang pemasaran, hal yang kerap terjadi dan merupakan suatu bentuk kesulitan adalah mempertahankan konsumen untuk dapat konsisten menggunakan hasil/produk yang dihasilkan produsen. Strategi dalam pemasaran juga memungkinkan seseorang dapat memilih berbagai alternatif tindakan yang mengarah pada tujuan dan misi 
perusahaan dengan cara yang paling baik (Dewi \& Agusrinal, 2014). Konsep pemasaran juga dapat terrefleksi pada sebuah tujuan organisasi, diantaranya: orientasi pada pengguna hasil produksi pada semua tataran aspek dan operasi, target dan besaran penjualan sesuai orientasi profit dengan cara yang ilmiah, usaha yang terpadu pada target sasaran bersama serta tanggung jawab sosial dan decision making (Pasigai, 2009).

Berbicara tentang strategi dan pemasaran, bukan hanya perusahaan saja yang melakukan upaya demikian, peguruan tinggi juga melakukan upaya yang sama demi keberlangsungan lembaganya. Seperti yang diketahui bersama bahwa persaingan ketat dalam merebut simpati dan minat calon mahasiswa gencar dilakukan melalui berbagai ajang promosi, bukan hanya perguruan tinggi negeri saja, perguruan tinggi swasta pun juga ikut 'mewarnai' dan melakukan hal yang serupa (Dharmawansyah, Cangara, \& Sultan, 2014).

Berbicara tentang promosi peguruan tinggi, faktor-faktor yang mempengaruhi keputusan mahasiswa untuk memilih program studi juga merupakan pertimbangan yang wajib dijadikan sebagai dasar, yakni: aspek fisik, jaminan kerja, biaya kuliah, persepsi dan promosi kampus (Mulyatini, Suharyati, \& Handayani, 2013). Faktor keluarga juga mempengaruhi siswa dalam belajarnya (Slameto, 2010). Selanjutnya faktor teman sebaya, relasi orang tua dan lingkungan 'tetangga' juga berkontribusi terhadap perilaku dan pengambilan keputusan (Andayani \& Ekowarni, 2016).

Sementara itu, hal yang umum dijumpai dalam sisi pemasaran adalah dengan cara penyebaran brosur, pemasangan baliho serta jasa media cetak dan elektronik. Strategi lainnya yang juga sering dijadikan daya tarik bagi calon mahasiswa baru yakni dengan menampilkan prestasi mahasiswa, menjanjikan suasana perkuliahan dan pendidikan yang berkualitas, sarana prasarana yang representatif dan biaya pendidikan yang murah, serta biasanya juga menebar testimoni dari para alumni yang sukses dan berhasil.

Banyaknya pilihan program studi, mendorong siswa untuk semakin mencari dan menemukan program studi yang sesuai dengan kriteria serta minatnya. Biasanya sebelum memilih program studi, calon mahasiswa akan mencari informasi tentang status akreditasi, biaya pendidikan, prospek pekerjaan, beasiswa atau bahkan daerah lokasi dimana perguran tinggi itu berada. Reputasi perguruan tinggi serta branding yang melekat pada sebuah institusi lembaga pendidikan tinggi umumnya juga menjadi daya tarik tersendiri bagi calon mahasiswa.

Berbicara tentang pengambilan keputusan, pilihan semestinya tediri dari dua atau lebih alternatif pilihan. Dalam memilih program studi, seorang calon mahasiswa seringkali tidak mengambil keputusan sendiri. Keputusan yang diambil biasanya berasal dari informasi guru, alumni, rekan serta orang tua. Suasana perkuliahan, kualitas dan mutu pendidikan yang baik, sarana prasarana yang representatif serta fasilitas penunjang lain yang ada, juga mempengaruhi calon mahasiswa dalam pengambilan keputusan bagi calon mahasiswa yang hendak berkuliah.

\section{METODE PENELITIAN}

Penelitian ini menggunakan pendekatan deskriptif kualitatif. Penelitian ini dilaksanakan di Kab. Banyuwangi, sampel ditentukan menggunakan 'quota sampling' atau dengan kata lain disesuaikan dengan kuota yang diinginkan peneliti (Sugiyono, 2013). Sampel sebanyak 200 orang siswa SMA Negeri dan Swasta yang dinyatakan lulus, 20 guru bimbingan konseling, 200 wali murid dan 50 mahasiswa baru yang sedang berkuliah di semester awal. Instrumen dalam penelitian ini berupa kuisioner tertutup dan kuisioner terbuka. Penelitian ini menggunakan 
pendekatan kualitatif, selanjutnya dianalisis menggunakan SWOT.

Berdasarkan hasil perhitungan uji validitas dan reliabilitas instrumen menggunakan SPSS, maka:

1. kuisioner untuk mahasiswa, valid. (N1 sampai N25) nilai Sig. $=0,000-0,023$. nilai Sig < 0,05. reliabel. (Re) alpha cronbach's sebesar 0,925, Nilai Re > 0,7.

2. kuisioner untuk calon mahasiswa. valid. (N1 sampai N28) nilai Sig. $=0,000$. nilai $\mathrm{Sig}<$ 0,05. reliabel. (Re) alpha cronbach's sebesar 0,980 , nilai $\operatorname{Re}>0,7$.

3. kuisioner untuk orang tua/wali. valid. (N1 sampai N27) nilai Sig. $=0,000$. nilai $\mathrm{Sig}<$ 0,05. reliabel. ( $\mathrm{Re})$ alpha cronbach's sebesar 0,977 , nilai $\operatorname{Re}>0,7$.

\section{HASIL PENELITIAN DAN PEMBAHASAN}

\section{Hasil Penelitian}

Dari 25 faktor ketertarikan mahasiswa untuk belajar di kampus UNIBA sebanyak 19 faktor masuk dalam kategori Tinggi dan sebanyak 6 faktor masuk kategori Sedang, secara keseluruhan tingkat ketertarikan mahasiswa untuk belajar di kampus UNIBA sebesar 71,1\% masuk dalam kategori Tinggi.

Dari 28 faktor ketertarikan calon mahasiswa untuk belajar di kampus UNIBA sebanyak 5 faktor masuk dalam kategori Tinggi dan sebanyak 23 faktor masuk kategori Sedang, secara keseluruhan tingkat ketertarikan calon mahasiswa untuk belajar di kampus UNIBA sebesar 63,4 \% masuk dalam kategori Sedang.

Dari 27 faktor ketertarikan orang tua calon mahasiswa untuk belajar di kampus UNIBA sebanyak 4 faktor masuk dalam kategori Tinggi dan sebanyak 23 faktor masuk kategori Sedang, secara keseluruhan tingkat ketertarikan orang tua calon mahasiswa untuk mendorong putra-putrinya belajar di kampus UNIBA sebesar 64,2 \% masuk dalam kategori Sedang.
Hasil Jawaban Guru Bimbingan Konseling SMA dan SMK Negeri dan Swasta di Banyuwangi, sehubungan dengan faktor kekurangan dan kelebihan kampus UNIBA.

Tabel 1. Hasil Jawaban Guru BK tentang Faktor Kekurangan dan Kelebihan Kampus UNIBA

\begin{tabular}{|c|c|c|}
\hline \multirow{2}{*}{ Faktor Kekurangan } & \multicolumn{2}{|c|}{ Guru BK } \\
\hline & SMA & SMK \\
\hline a. Layanan & 1 & \\
\hline b. Kegiatan Kampus & 1 & \\
\hline c. Sosialisasi & 4 & 1 \\
\hline d. Kerjasama & 1 & 1 \\
\hline e. Fisik Gedung & 2 & $\mathrm{I}$ \\
\hline f. Isu Konflik Internal & 3 & 1 \\
\hline g. Program Studi & 1 & \\
\hline h. SDM & 1 & \\
\hline i. Akreditasi & 1 & 1 \\
\hline Jumlah & 15 & 5 \\
\hline \multicolumn{3}{|l|}{ Faktor Kelebihan } \\
\hline a. Reputasi Kampus & 5 & \\
\hline b. Jumlah Program Studi & & 2 \\
\hline c. Biaya Kuliah & 1 & 1 \\
\hline d. Daya Saing & 1 & \\
\hline e. Kenyamanan Belajar & 1 & \\
\hline f. Jarak Kampus & 5 & 3 \\
\hline $\begin{array}{l}\text { g. Kemudahan Bekerja Setelah } \\
\text { Lulus }\end{array}$ & 1 & \\
\hline Jumlah & 14 & 6 \\
\hline
\end{tabular}

Dari tabel 1. di atas menunjukkan data hasil jawaban guru Bimbingan Konseling sesuai dengan kekurangan dan kelebihan kampus UNIBA, diantaranya:

1. kekurangan, meliputi:

a. sosialisasi dan informasi yang belum maksimal terhadap siswa, 
b. masih sering banyak kabar miring (isu konflik internal) dalam kampus uniba dan butuh diklarifikasi,

c. fisik dan tampilan gedung yang kurang menarik dari luar,

d. kurang menjalin kerjasama dengan sekolah-sekolah di banyuwangi,

e. Peringkat Akreditasi

f. prodi yang masih terbatas,

g. kurang bagus dalam pelayanan,

h. kurang kegiatan di luar kampus

i. SDM Kampus
2. kelebihan, meliputi:

a. jarak dan lokasi kampus yang strategis dekat dengan pusat kota Banyuwangi,

b. merupakan kampus tertua dan menghasilkan banyak lulusan

c. banyak pilihan program studi

d. biaya kuliah yang terjangkau, tenaga pengajar/dosen yang berkualitas,

e. mempunyai daya saing yang tinggi,

f. tempat belajar yang nyaman, dan

g. Kemudahan berkerja setelah lulus kuliah.

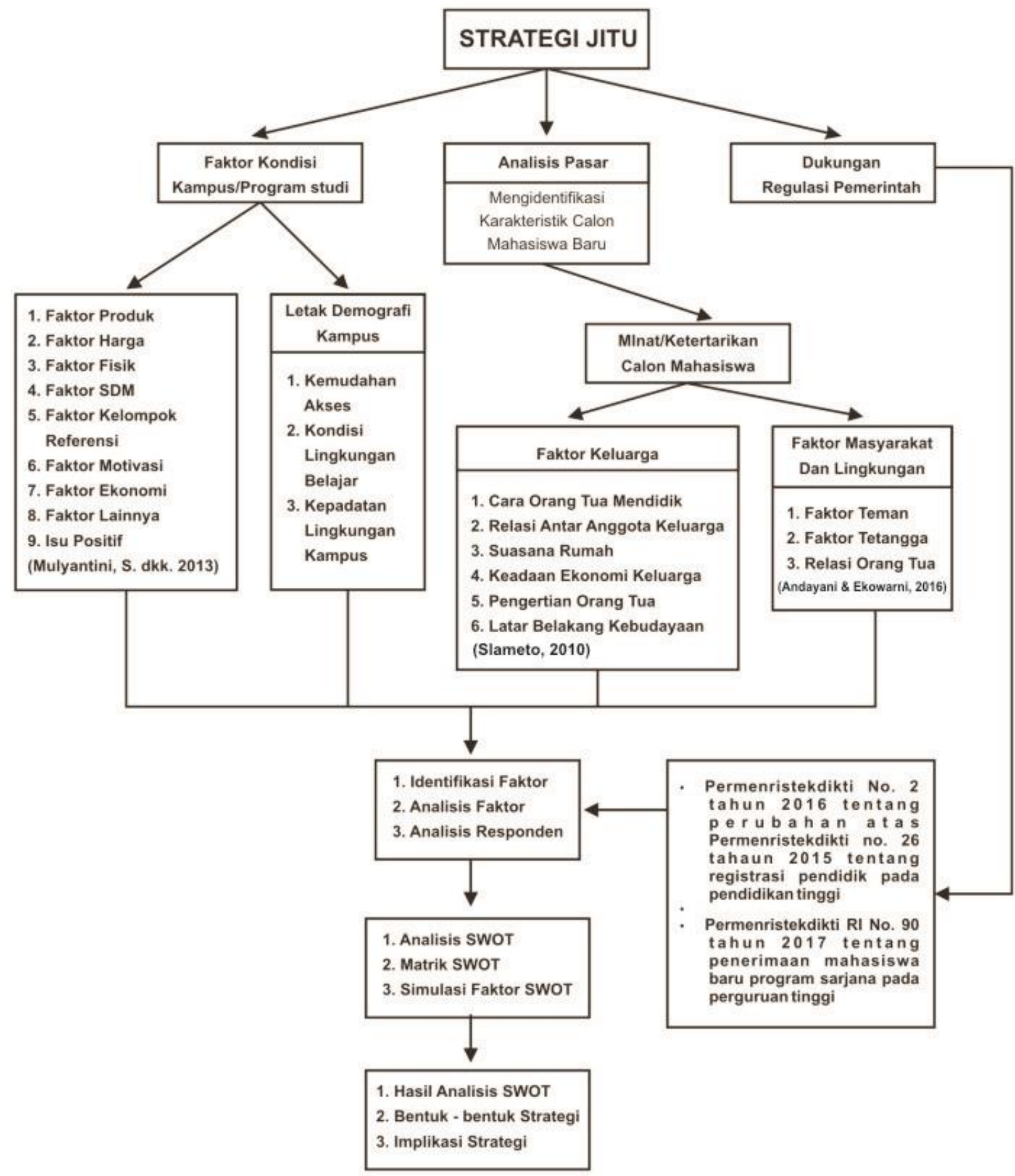




\section{Gambar 1. Diagram Alir Penelitian}

Pada gambar 1 tentang diagram alir penelitian menunjukkan bahwa, strategi jitu didapatkan dengan mempertimbangkan faktorfaktor yang mempengaruhi ketertarikan calon mahasiswa dalam menentukan keputusan dalam berkuliah. Faktor yang dimaksud adalah faktor kondisi kampus, faktor keluarga dan faktor masyarakat dan lingkungan. Ketiga faktor tersebut kemudian dianalisis dan dilanjutkan dengan analisis SWOT, membuat matrix SWOT dan mensimulasikannya.

\section{Analisis SWOT}

Menentukan faktor Strenght (kekuatan), Weakness (kelemahan), Opportunity (peluang), dan Threat (ancaman) diambil dari persepsi mahasiswa UNIBA, calon mahasiswa, orang tua calon mahasiswa, dan guru Bimbingan Konseling. Faktor-faktor tersebut diambil dari faktor yang berpengaruh (hasil analisis faktor) dan tingkat ketertarikan (hasil pengukuran angket).

Dari tabel matrik faktor diketahui bahwa skor faktor strenght sebesar 4,40; skor faktor weakness sebesar 3,65; skor faktor opportunity sebesar 3,75; dan skor faktor threat sebesar 3,50. Hasil perhitungan masing-masing skor digunakan untuk menentukan posisi kuadran strategi dengan sumbu koordinat $\mathrm{x}$ dan y. Adapun untuk mencari nilai sumbu koordinat $\mathrm{x}$ dan y dapat dihitung dengan rumus sebagai berikut:

$$
\begin{aligned}
\mathrm{X} & =\frac{\text { Nilai Strenght-Nilai Weakness }}{2} \\
& =\frac{4,40-3,65}{2} \\
& =0,38 \\
\mathrm{Y} & =\frac{\text { Nilai Opportunity-Nilai Threat }}{2} \\
& =\frac{3,75-3,50}{2} \\
& =0,13
\end{aligned}
$$

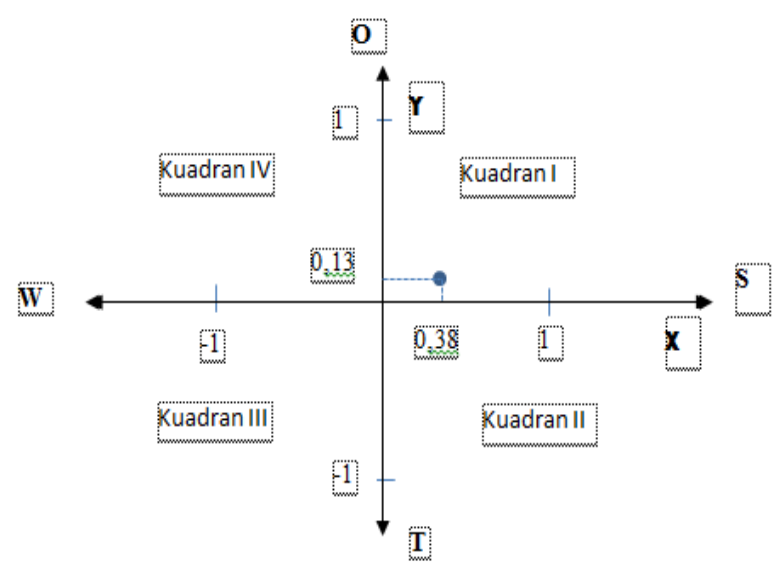

Gambar 2. Kuadran SWOT

Berdasarkan gambar 2, sumbu koordinat di atas diketahui bahwa hasil perhitungan matrik faktor SWOT menunjukkan posisi kuadran I, jadi dapat dikatakan bahwa penerapan strategi SWOT yang dilakukan bersifat agresif. Dengan demikian kampus mempunyai peluang dan kekuatan untuk dapat memanfaatkan peluang yang ada (Nourlette \& Hati, 2017).

\section{Strategi (S-O)}

1. Melakukan kegiatan pengenalan kampus yang bersifat promosi pada lembaga pendidikan di bawahnya (SMA/SMK) dengan melibatkan dosen dan mahasiswa berprestasi, yaitu:

a. Melakukan hubungan kerja sama dengan pihak sekolah SMA/SMK

b. Melakukan tatap muka langsung dengan guru, siswa, dan orang tua/wali murid dengan mengirimkan delegasi kampus yang terdiri dari dosen dan mahasiswa yang berprestasi khususnya dari alumni sekolah tersebut sehingga dapat menjadi ajang percontohan bagi siswa-siswa sekolah tersebut

c. Para mahasiswa yang berprestasi memberikan training coach (mis. Jurusan olahraga tertentu) pada para siswa tersebut sehingga menjadi daya tarik siswa untuk mengikuti jejaknya. 
d. Membuat event/kejuaraan olahraga antar siswa di sekolah tersebut dengan sponsor utama kampus UNIBA dan memberi hadiah beasiswa pendidikan bagi juara/finalis untuk melanjutkan kuliah di kampus UNIBA.

2. Membuat event/kejuaraan olahraga, lombah karya tulis ilmiah antar pelajar sekolah seKabupaten Banyuwangi.

3. Lebih sering melakukan aktivitas kegiatan olahraga rekreasi yang bersifat kemasyarakatan pada waktu liburan kerja (seperti: jalan sehat, sepeda bersama, pendakian gunung, dan lain-lain).

4. Lebih gencar melakukan kegiatan promosi kampus dengan menyebarkan brosur-brosur profil kampus pada lembaga-lembaga pendidikan baik pendidikan formal maupun non formal dengan memberikan daya tarik berupa keringanan biaya/beasiswa gratis bagi para 100 pendaftar pertama pada masing-masing jurusan.

5. Membuat suatu wadah /organisasi perkumpulan di bawah naungan kampus UNIBA yang menjadi unggulan potensi produk masyarakat Banyuwangi (misal: bidang seni budaya, olahraga, perniagaan, industri, dan lain-lain).

\section{Strategi (S-T)}

1. Meningkatkan aktivitas kinerja seluruh elemen kampus (khususnya pihak pengelolah, dosen, dan mahasiswa), seperti: meningkatkan pelayanan pada masingmasing bidang fungsional, peningka tan kualitas dosen pengajar, dan pembentukan badan-badan kemahasiswaan.

2. Menyatukan visi dan misi dan mempererat hubungan kerja sama seluruh elemen kampus khususnya pihak pengelolah, dosen, dan mahasiswa.

3. Meningkatkan kualitas akreditasi pada masing-masing jurusan (prodi) khususnya pada jurusan (prodi) yang mempunyai nilai akreditasi yang rendah.
4. Memanfaatkan jurusan (prodi) yang mempunyai akreditasi baik sebagai ujung tombak promosi kampus.

5. Lebih fokus mendukung aktivitas kegiatan badan-badan kemahasiswaan yang bersifat pengenalan dan promosi kampus, seperti: kegiatan mapala, ukm, dan lain sebagainya.

6. Meningkatkan kesadaran pada masingmasing komponen kampus (khususnya pihak pengelolah, dosen, dan mahasiswa) untuk tetap mejaga diri terhadap adanya isuisu dari luar yang bersifat memecah belah keutuhan kampus.

\section{Strategi (W-O)}

1. Meningkatkan kepercayaan masyarakat pada kampus UNIBA sehingga menjadi kampus favorit di Kabupaten Banyuwangi, dengan banyak melakukan kegiatan yang bersifat sosial.

2. Meningkatkan kualitas pendidikan khusunya jurusan olahraga dan menambah intensitas kegiatan event/kejuaraan olahraga dengan melakukan kerjasama dengan para sponsor

3. Meningkatkan kualitas kelulusan

4. Meningkatkan hubungan dengan para guru SMA/SMK khususnya yang berasal dari alumni UNIBA, dengan tujuan mengajak para guru alumni UNIBA berperan aktif dalam upaya meningkatkan kepercayaan siswa pada kampus UNIBA.

5. Melakukan hubungan pendekatan dengan pemerintah melalui dinas pendidikan daerah

\section{Strategi (W-T)}

1. Memperbaiki kualitas pendidikan dan pelayanan kampus UNIBA

2. Menjaga keutuhan dan kekompakan antar komponen di kampus UNIBA

3. Melakukan kontrol dan pengendalian tentang pengelolahan keuangan kampus UNIBA

4. Melakukan kerjasama dengan lembaga perbangkan khususnya pemerintah dalam upaya menstabilkan masalah pendanaan operasional kampus UNIBA. 
5. Mengaktifkan dan mendukung kegiatan lembaga/badan kemahasiswaan.

Perumusan kesimpulan strategi di atas didapat dari analisis kuisioner responden tentang ketertarikan mahasiswa, calon mahasiswa dan orang tua mahasiswa untuk memilih kampus UNIBA.

\section{Pembahasan}

Berdasarkan data di atas, menunjukkan bahwa ketertarikan mahasiswa untuk berkuliah pada program studi yang sedang dijalani termasuk dalam kategori tinggi, untuk itu strategi promosi yang dapat dilakukan adalah strategi berbasis mahasiswa, yang artinya jika mahasiswa puas atas layanan akademik, fasilitas perkuliahan dan suasana kampus yang mengesankan maka, kepuasan akan didapatkan, selanjutnya akan merekomendasi pada calon mahasiswa yang akan berkuliah.

Pada sisi orang tua mahasiswa, sesuai data yang didapat peneliti menunjukkan kategori sedang, artinya dalam mendorong putra-putrinya/calon mahasiswa dalam berkuliah masih perlu ada peningkatan. Hal demikian dapat berarti bahwa, strategi dengan pendekatan melalui orang tua perlu dioptimalkan, mengingat salah satu faktor pengambilan keputusan dan rekomendasi juga

berasal dari saran orang tua calon mahasiswa.

Pada sisi calon mahasiswa/siswa kelas XII SMA/SMK di Banyuwangi menunjukkan kategori ketertarikan sedang, hal demikian merupakan bukti bahwa belum maksimalnya kegiatan promosi, brand image kampus yang tidak ada, passion calon mahasiswa yang belum terbentuk, kurangnya sosialisasi yang intens dan berkelanjutan serta secara umum belum sesuai dengan keinginan siswa secara keseluruhan.

Selanjutnya pada sisi guru bimbingan konseling, ditemukan kekurangan-kekurangan yang harus terselesaiakan, diantaranya pemulihan nama besar lembaga pasca konflik internal yang pernah terjadi, kurang sosialisasi, kerjasama yang belum optimal dan sebagainya. Dengan demikian strategi yang mungkin dilaksanakan adalah menyiapkan SDM yang berkompeten dalam bidang ilmu komunikasi dan hubungan masyarakat yang dapat meyakinkan semua pihak tentang kondisi kampus, visi dan misi, rencana induk pengembangan dan rencana strategi pengembangan kampus kedepan.

\section{SIMPULAN DAN SARAN}

\section{Simpulan}

Penerapan strategi SWOT yang dilakukan bersifat Agresif, bentuk strateginya meliputi:

1. Strategi (S-O) yaitu: a) aktif melakukan kerja sama pada lembaga pendidikan SMA/SMK, b) Membuat event/kejuaraan atau lombah antar pelajar sekolah seKabupaten Banyuwangi, c) Melakukan kegiatan olahraga rekreasi yang bersifat kemasyarakatan, d) memberikan daya tarik keringanan biaya/beasiswa gratis bagi para 100 pendaftar pertama, e) Membuat wadah perkumpulan yang menjadi unggulan potensi produk masyarakat Banyuwangi.

2. Strategi (S-T) yaitu: a) Meningkatkan kinerja seluruh elemen kampus dan pelayanan bidang fungsional, b) Menyatukan visi dan misi guna meningkatkan kualitas akreditasi, c) Memanfaatkan jurusan (prodi) yang mempunyai akreditasi baik sebagai ujung tombak promosi, d) memberi dukungan penuh aktivitas kegiatan badan-badan kemahasiswaan, e) menjaga kesadaran diri terhadap adanya isu-isu yang bersifat memecah belah keutuhan kampus.

3. Strategi (W-O) yaitu: a) melakukan kegiatan yang bersifat sosial yang bertujuan meningkatkan persepsi dan apresiasi masyarakat, b) Menambah intensitas kegiatan event/kejuaraan olahraga dengan melibatkan para sponsor, c) mengajak guru alumni UNIBA untuk berperan aktif dalam 
upaya meningkatkan apresiasi siswa, d) melakukan pendekatan dengan pemerintah melalui dinas pendidikan daerah.

4. Strategi (W-T) yaitu: a) Memperbaiki kualitas pendidikan dan pelayanan, b) Menjaga keutuhan dan kekompakan antar komponen, c) Melakukan kontrol dan pengendalian dalam pengelolahan keuangan, d) Melakukan kerjasama dengan lembaga perbangkan dalam upaya menstabilkan masalah pendanaan operasional.

\section{Saran}

Berdasarkan hasil kajian penelitian strategi tepat dalam meningkatkan jumlah mahasiswa baru dalam persaingan antar perguruan tinggi di atas, disarankan menggunakan strategi penguatan pada sisi internal dan eksternal kampus, diantaranya:

\section{Sisi internal}

a. Kampus mampu menjamin suasana proses pembelajaran yang menyenangkan dengan mengoptimalkan semua potensi yang tersedia demi kepuasan mahasiswa dalam menempuh proses studinya.

b. Melaksanakan pelayanan prima akademik pada mahasiswa

c. Menguatkan SDM Dosen dan tenaga kependidikan

d. Meningkatkan sarana dan prasarana yang ada

e. Menyelenggarakan job fair bagi mahasiswa dan alumni

2. Sisi eksternal

a. Menjalin kemitraan yang baik dengan semua pihak dan stake holder

b. Menjadi penyelenggara pada even-even tertentu di dalam maupun di luar kampus sebagai bentuk promosi yang berkelanjutan

c. Mampu memastikan pada semua pihak bahwa kampus berstatus bebas konflik atau predikat kampus sehat

d. Jaminan mendapat beasiswa dari internal kampus dan sponsor e. Menambah pilihan-pilihan prodi baru yang sesuai dengan minat calon mahasiswa disesuaikan dengan analisis kebutuhan.

\section{DAFTAR PUSTAKA}

Andayani, F. T., \& Ekowarni, E. (2016). Peran Relasi Orang Tua-Anak dan Tekanan Teman Sebaya terhadap Kecenderungan Perilaku Pengambilan Risiko. Gadjah Mada Journal Of Psychology, 2(2), 138-151. doi:10.22146/gamajop.33097

Dewi, D., \& Agusrinal. (2014). Perancangan Strategi Pemasaran Pada Produk Anyaman Pandan. Jurnal Sains, Teknologi dan Industri, 11(2), 175-184. doi:10.24014/SITEKIN.V11I2.745

Dharmawansyah, S., Cangara, H., \& Sultan, M. I. (2014). Strategi Promosi Dalam Meningkatkan Jumlah Mahasiswa Pada Politeknik Negeri Media Kreatif Makassar. KAREBA : Jurnal Ilmu Komunikasi, 3(2), 256-263. doi:https://doi.org/10.31947/kjik.v3i4.5 99

Garaika, \& Feriyan, W. (2018). Promosi Dan Pengaruhnya Terhadap Terhadap Animo Calon Mahasiswa Baru Dalam Memilih Perguruan Tinggi Swasta. Jurnal Aktual STIE Trisna Negara, 16(1), 21-27. doi:10.47232/aktual.v16i1.3

Maxsi, A. (2015). Pengklasifikasian Karakteristik Mahasiswa Baru Dalam Memilih Program Studi Menggunakan Analisis Cluster. Jurnal Informatika, 2(1), 181-188. doi:https://doi.org/10.31294/ji.v2i1.58

Mulyatini, S., Suharyati, \& Handayani, T. (2013). Faktor-Faktor Yang Berpengaruh Terhadap Keputusan Memilih Program Studi. Jp.Feb.ONSOED, 3(1), 1-15. Retrieved 
from

http://jp.feb.unsoed.ac.id/index.php/sca

-1/article/viewFile/243/248

Nourlette, R. R., \& Hati, S. W. (2017). Penentuan Strategi Dengan Pendekatan Analisis SWOT Pada Hotel Nongsa Point Marina \& Resort Dalam Menghadapi Persaingan Bisnis. Inovbiz: Jurnal Inovasi dan Bisnis, 5(1), 83-102.

doi:https://doi.org/10.35314/inovbiz.v5 i1.174

Pasigai, M. A. (2009). Pentingnya Konsep Dan Strategi Pemasaran Dalam Menghadapi Persaingan Bisnis. Jurnal Ilmu Ekonomi Studi Pembangunan, 5(1), 51-56. doi:https://doi.org/10.26618/jeb.v5i1.5 81

Permenristekdikti. (2016). Perubahan Atas Permenristekdikti Nomor 26 Tahun 2015 Tentang Registrasi Pendidik Pada Perguruan Tinggi. Lampiran BAB III
Poin C Tentang Perhitungan Rasio Dosen dan Mahasiswa. Jakarta.

Slameto. (2010). Belajar dan Faktor-faktor yang Mempengaruhinya. Jakarta: Rineka Cipta.

Sopandi, E. (2011). Strategi Promosi Penerimaan Mahasiswa Baru Untuk PTS (Tinjauan Atas Kegiatan Promosi PTS Di Jawa Barat Tahun 2010). Manajerial, $\quad 10(1), \quad$ 87-101. doi:https://doi.org/10.17509/manajerial .v10i1.1828

Sugiyono. (2013). Metode Penelitian Kuantitatif Kualitatif Dan $R \& D$. Bandung: CV. Alfabeta.

Zaman, J. S. (2017). Analisis Pengaruh Brand Image Corporate (Citra Merek Perusahaan) Terhadap Keputusan Pembelian Pada Planet Computer Tasikmalaya. Jurnal ECONOMICA, 2(1), 36-41. Retrieved from https://pdfcoffee.com/jurnalpemasaranpdf-pdf-free.html 